\title{
ORIGINAL
}

\section{Non-mitochondrial calcium uptake and release by chondrocyte: Role of ATP, phosphate ions and inositol triphosphate}

\author{
Toshikazu Tokuoka, Osamu Oshima, Saburo Kakuta, Masao Nagumo, \\ Kristine Debolt* and Irving M. Shapiro*
}

Second Department of Oral and Maxillofacial Surgery, School of Dentistry, Showa University, 2-1-1 Kitasenzoku, Ohta-ku, Tokyo, 145, Japan

(Chief : Prof. Masao Nagumo)

* Department of Biochemistry, School of Dental Medicine, University of Pennsylvania, 4001 Spruce Street, Philadelphia, PA 19104-6003, USA

(Chief : Prof. Irving M. Shapiro)

[Accepted for publication: December 12, 1992]

Key words : chondrocyte/non-mitochondrial/calcium/uptake/release

\begin{abstract}
The objective of this investigation was to evaluate $\mathrm{Ca}^{2+}$ binding characteristics of the endoplasmic reticulum of chick chondrocytes. Using a permeabilized cell preparation in which $\mathrm{Ca}^{2+}$ uptake into mitochondria was blocked with ruthenium red, we measured cation uptake by a rapid centrifugation procedure. In terms of $\mathrm{Ca}^{2+}$ binding, we demonstrated that uptake was mediated by ATP and blocked by treatment with vanadate. To determine whether or not $\mathrm{Ca}^{2+}$ binding proteins existed in these cells we isolated endoplasmic reticulum from chondrocytes. Using a ${ }^{45} \mathrm{Ca}$ overlay technique, we demonstrated the presence of $\mathrm{Ca}^{2+}$ binding proteins that were of the same size as the reticuloplasmins. We measured $\mathrm{Ca}^{2+}$ release characteristics of avian chondrocyte endoplasmic reticulum. The cells were sensitive to $1,4,5$-inositol triphosphate $\left(\mathrm{IP}_{3}\right)$ - the rate and extent of $\mathrm{Ca}^{2+}$ release from this pool was similar in magnitude to that of other tissues. To evaluate the effects of metabolic factors on cation transport, we examined the effect of glucose, glucose 6-phosphate and inorganic phosphate $(\mathrm{Pi})$. We noted that there was minimal phosphatase activity and exogenous glucose 6phosphate did not stimulate $\mathrm{Ca}^{2+}$ transport. However, Pi markedly increased ATP supported $\mathrm{Ca}^{2+}$ uptake. This finding suggests that any mechanism that could serve to elevate the intracellular $\mathrm{Pi}$ concentration, whether by hydrolysis of organic phosphate esters or by supplementing the cytosolic $\mathrm{Pi}$ concentration, would serve to maintain $\mathrm{Ca}^{2+}$ within the endoplasmic reticulum. The results of these studies indicate a central role of intracellular $\mathrm{Pi}$ in chondrocyte $\mathrm{Ca}^{2+}$ transport.
\end{abstract}

\section{Introduction}

The mechanism by which chondrocytes control intracellular ion transport prior to, and during, mineral deposition is not understood.
Results of studies with other cell types indicate that when ion transients occur there is a dramatic alteration in cell function. For example, it is known that the intracellular inorganic phosphate $(\mathrm{Pi})$ level regulates carbohydrate metabolism and activates oxidative 
phosphorylation. In terms of mineralization related activities, $\mathrm{Pi}$ modulates the rate of $\mathrm{Ca}^{2+}$ transport across lipid membranes ${ }^{1)}$. In addition, in an earlier study, we showed that a low molecular weight phosphorylated compounds may provide $\mathrm{Pi}$ for mineral formation $^{2)}$.

The intracellular $\mathrm{Ca}^{2+}$ concentration has a profound effect on cellular activity. This ion is an important cofactor for membrane ATPase as well as the enzymes associated with the tricarboxylic acid cycles). Mitochondria have a high affinity for $\mathrm{Ca}^{2+}$. Indeed, as this cation is taken up avidly by isolated mitochondria, the presence of $\mathrm{Ca}^{2+}$ deposit in this organelle has been thought to be linked to mineralization of the extracellular matrix ${ }^{4,5)}$. Recent studies, however, indicate that mitochondrial calcium transport may not be linked to mineral deposition, since, in both excitable as well as some nonexcitable tissues the endoplasmic (sarcoplasmic) reticulum serves as a major $\mathrm{Ca}^{2+}$ buffer ${ }^{6,7)}$.

Calsequestrin, a protein present in the terminal cisternae of the endoplasmic reticulum, is a $\mathrm{Ca}^{2+}$ binding protein that has a high capacity and moderate affinity for $\mathrm{Ca}^{2+}{ }^{2}$ ). In some tissues, $\mathrm{Ca}^{2+}$ has been located in specific cytoplasmic structures that are designated as "calciosomes"9). It is thought that $\mathrm{Ca}^{2+}$ located in the calciosome is in equilibrium with cytosolic $\mathrm{Ca}^{2+}$. Calcium can be released from the endoplasmic reticulum by the hydrolysis of phosphatidylinositol and the formation of $1,4,5$-inositol triphosphate $\left(\mathrm{IP}_{3}\right)$. When this compound is bound to a specific receptor protein in the endoplasmic reticulum, there is a rapid release of bound $\mathrm{Ca}^{2+}$. Another pathway for release of bound $\mathrm{Ca}^{2+}$ is by the synthesis of factors such as those associated with carbohydrate metabolism ${ }^{10-12)}$. Irrespective of the release mechanism, a transient elevation in cytosolic $\mathrm{Ca}^{2+}$ would change the activity of a number of $\mathrm{Ca}^{2+}$ dependent enzymes $^{13}$.

The objective of this study are four fold : first, to ascertain whether chondrocytes accumulate $\mathrm{Ca}^{2+}$ at the level of the endoplasmic reticulum; second, to determine whether calsequestrin-like proteins are expressed in these cells ; third, to characterize nonmitochondrial energy supported $\mathrm{Ca}^{2+}$ uptake and release by cartilage; cells and fourth, using a plasma membrane permeabilizing procedure, to examine the uptake of $\mathrm{IP}_{3}$ and glucose 6-phosphate as modulators of $\mathrm{Ca}^{2+}$ flux.

\section{Materials and Methods}

\section{Cells}

Chondrocytes were isolated from the proximal tibial growth cartilage of the 8 week old White Rock chick using a collagenase digestion procedure. The cells were maintained in the primary culture of DMEM supplemented with $10 \%$ fetal calf serum and antibiotics in $95 \%$ air and $5 \% \quad \mathrm{CO}_{2}$ for 24 hours in microbiological tissue culture dishes. As red blood cells attach to the surface of the dish, the procedure permitted separation of blood cells from chondrocytes. The chondrocytes were collected by centrifugation and washed. The cells were over $90 \%$ vital as judged by trypan blue exclusion and they exhibited a high energy charge ratio (above 8.9). Liver cells were also collected in the same manner.

For evaluation of $\mathrm{Ca}^{2+}$ binding proteins in chondrocytes, cells were isolated from the tibial epiphysis of 19 day chick embryos. The cartilage was digested with collagenase and the cells were collected and maintained in culture using procedures that we described previously14.) Secondary cultures were harvested at 7 days.

\section{Permeabilization}

The used procedure was very similar to that described by other workers ${ }^{15}$. Briefly, cells were washed in a basic buffer containing 20 $\mathrm{mM} \mathrm{NaCl}, 100 \mathrm{mM} \mathrm{KCl}, 5 \mathrm{mM} \mathrm{MgCl}$, and $10 \mathrm{mM}$ HEPES at $\mathrm{pH}$ 7.2. Chondrocytes (30 $\times 10^{6}$ ) were permeabilized by treatment with digitonin in basic buffer $(80 \mu \mathrm{g} / \mathrm{m} l)$ for 2 mimutes at $37^{\circ} \mathrm{C}$. This treatment resulted in permeabilization of the cell membrane as indicated by trypan blue exclusion. Subsequent evaluation by electron microscopy revealed few changes in the morphology of the endoplasmic reticulum. The permeabilized cells were then washed and the pellet was suspended in a buffer containing $1 \mathrm{mM}$ EDTA and $3 \mu \mathrm{M}$ ruthenium red for 3 minutes at room temperature. The presence of the ruthenium red 
resulted in a $30-40$ fold decrease in calcium uptake by the permeabilized cells.

Calcium Uptake by Permeabilized Cells

The method used was similar to that described by Wolf, et al15). The procedure was modified by collecting the cells by centrifugation. Following permeabilization, the cells were isolated by centrifugation at $2,000 \mathrm{~g}$, washed and resuspended in the basic buffer containing $10 \mu \mathrm{Ci}{ }^{45} \mathrm{CaCl}_{2}(0.6 \mathrm{M})$. For those experiments, designed to measure $\mathrm{Ca}^{2+}$ uptake in the presence of ATP, the concentrations of ATP, $\mathrm{Mg}^{2+}, \mathrm{Ca}^{2+}$, and EGTA were determined using the computer program generated from the dissociation constants of the various ionized chemical species. Chondrocyte calcium uptake values obtained using the computer program were not substantially different from those obtained using the basic buffer system with the final $\mathrm{Ca}^{2+}$ concentration adjusted to $64 \mu \mathrm{M}$ with $\mathrm{CaCl}_{2}$.

Electrophoretic Separation of $\mathrm{Ca}^{2+}$ Binding Proteins

Following 7 days in culture, cells were washed first with calcium and magnesium-free Hank's balanced salt solution to remove serum and then with phosphate buffered saline (PBS) at $\mathrm{pH}$ 7.4. The cells were homogenized by 3 freeze-thawing cycles and completeness of homogenization was checked by microscopy. The homogenate was centrifuged at $14,000 \mathrm{~g}$ for 20 minutes to sediment nuclei, membranes, mitochondria, and lysosomes. The supernate was stored on ice. The sediment was washed with PBS and recentrifuged at $14,000 \mathrm{~g}$. The two supernatants were combined and centrifuged at $105,000 \mathrm{~g}$ for 3 hours. The sediment was subjected to SDS-PAGE in 10\% acrylamide mini gel. The proteins were transferred to nitrocellulose and the membrane was incubated in a buffer $(60 \mathrm{mM} \mathrm{KCl}, 5 \mathrm{mM} \mathrm{Mg}$ $\mathrm{Cl}_{2}$, and $10 \mathrm{mM}$ imidazole- $\mathrm{HCl}$ at $\mathrm{pH} 6.8$ ) containing $1 \mathrm{mCi}{ }^{45} \mathrm{Ca}$ for 10 minutes using the method described by Maruyama, et al ${ }^{16)}$. Binding was assessed by autoradiography.

Chemical Assays

Total calcium was determined by atomic absorption spectrophotometry; protein was assayed using the method of Lowry, et al ${ }^{17)}$; glucose 6-phosphatase activity was assessed using the technique described by Watts, et al18).
Data were expressed as Mean \pm S.E. of three or four experiments.

\section{Results}

The first series of experiments were directed at characterizing conditions that were optimum for non-mitochondrial $\mathrm{Ca}^{2+}$ uptake into the permeabilized cells. Calcium uptake into the permeabilized cells measured over a 15 minute time period was $49.84 \pm 5.8 \mathrm{nmol} / \mathrm{mg}$ protein/ min. When energy supported mitochondrial $\mathrm{Ca}^{2+}$ uptake was inhibited by treating the cells with ruthenium red, the mean $\mathrm{Ca}^{2+}$ uptake was reduced to $3.2 \pm 0.5 \mathrm{nmole} / \mathrm{mg}$ protein/ min (Fig. 1). Hence, treatment of the cells with the inhibitor resulted in a 10 fold decrease in $\mathrm{Ca}^{2+}$ uptake. The study also showed that non-mitochondrial $\mathrm{Ca}^{2+}$ uptake was small in comparison with uptake into the mitochondria.

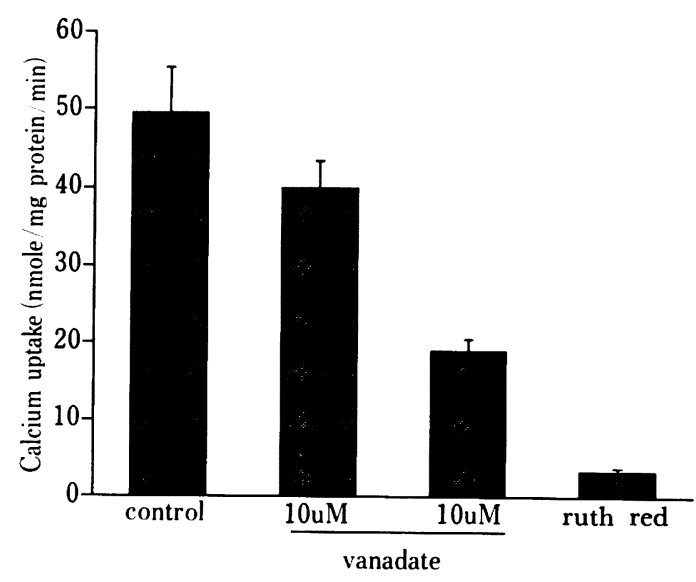

Fig. 1 The effect of inhibitors on $\mathrm{Ca}^{2+}$ uptake by chondrocytes. Chondrocytes were permeabilized by exposure to digitonin for 2 minutes and then treated with vanadate (10 and $100 \mu \mathrm{M}$ ) or ruthenium red $(3 \mu \mathrm{M})$ for 3 minutes. Control cells were not exposed to an inhibitor. Chondrocytes were washed and suspended in a buffer that contained $2 \mathrm{mM}$ ATP, $20 \mathrm{mM} \mathrm{NaCl}, 100 \mathrm{mM} \mathrm{MgCl}, 10 \mathrm{mM}$ HEPES, and $10 \mu \mathrm{Ci}{ }^{45} \mathrm{CaCl}_{2}$ (adjusted with $\mathrm{CaCl}_{2}$ to give a final concentration

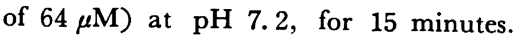
Calcium uptake was determined by scintillation counting. 


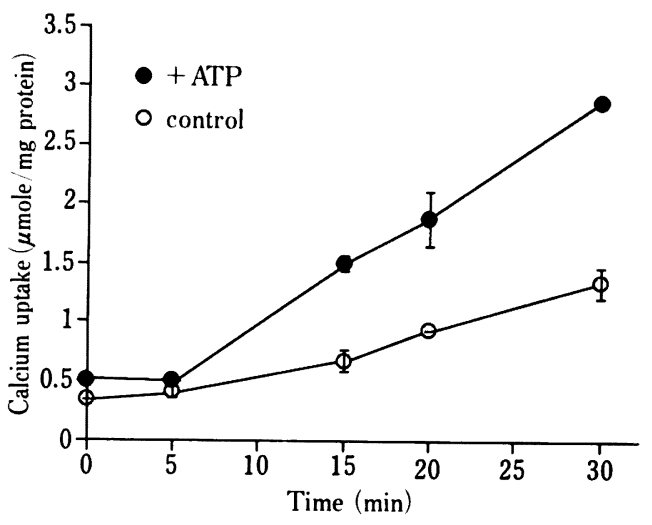

Fig. 2 Time dependent uptake of $\mathrm{Ca}^{2+}$ by chondrocytes. Permeabilized ruthenium redtreated chondrocytes were incubated with $10 \mu \mathrm{Ci}{ }^{45} \mathrm{CaCl}_{2}(64 \mu \mathrm{M})$ at $37^{\circ} \mathrm{C}$ in the presence (closed circles) and absence (open circles) of $2 \mathrm{mM}$ ATP. Calcium uptake was determined by removing cells and measuring their ${ }^{45} \mathrm{Ca}$ content following rapid centrifugation.

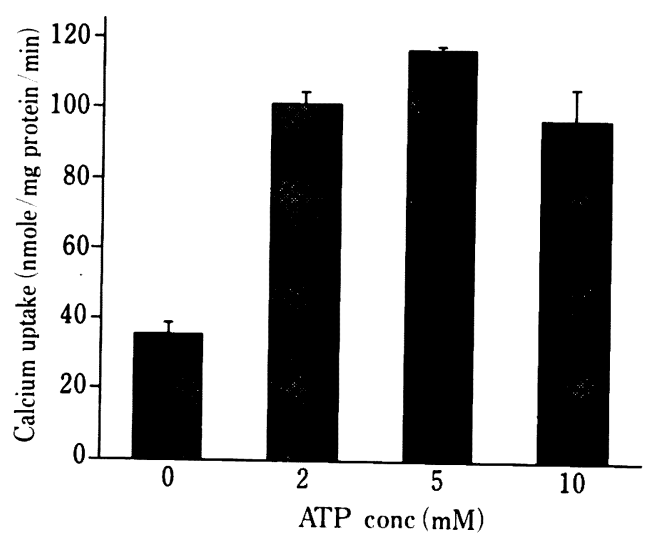

Fig. 3 ATP-supported $\mathrm{Ca}^{2+}$ uptake by permeabilized chondrocytes. Permeabilized cells were treated with ruthenium red and $\mathrm{Ca}^{2+}$ uptake was determined over a 15 minute time period in the presence of ATP (0-10 mM).

In a separate series of experiments the effect of vanadate on $\mathrm{Ca}^{2+}$ uptake was examined. Figure 1 shows that treatment of chondrocytes with vanadate resulted in a dose dependent decrease in $\mathrm{Ca}^{2+}$ levels in chondrocytes. As vanadate is an inhibitor of endoplasmic reticulum ATPase activity, it is probable that $\mathrm{Ca}^{2+}$ uptake into the endoplasmic reticulum is de-

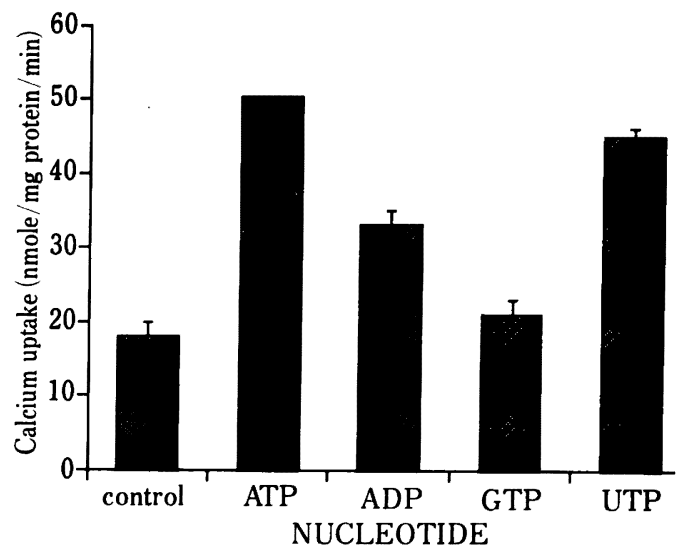

Fig. 4 Nucleotide-supported $\mathrm{Ca}^{2+}$ uptake by permeabilized chondrocytes. Permeabilized cells were treated with ruthenium red and $\mathrm{Ca}^{2+}$ uptake was determined over a 15 minute time period in the presence of $2 \mathrm{mM}$ ATP, ADP, GTP, and UTP.

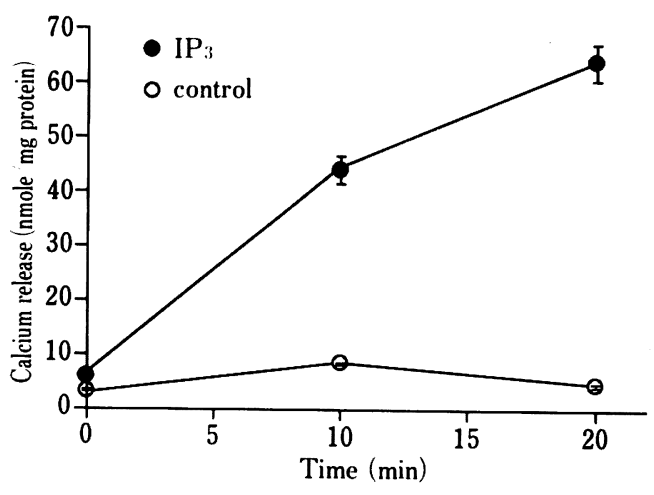

Fig. 5 Effect of $\mathrm{IP}_{3}$ on $\mathrm{Ca}^{2+}$ release from chondrocytes. Cells were permeabilized, treated with ruthenium red and loaded with $\mathrm{Ca}^{2+}$ in the presence of ATP. IP $(2 \mu \mathrm{M})$ was added to the cell suspension (closed circles). At 0,10 , and $20 \mathrm{~min}$ utes, aliquots of the supernatant were removed and counted. Loss of calcium from permeabilized chondrocytes that were not exposed to $\mathrm{IP}_{3}$ are also shown (open circles).

pendent on the presence of an active ATPase system.

Figure 2 shows that chondrocytes accumulated $\mathrm{Ca}^{2+}$ in a linear fashion over a 30 minute time period. In the presence of $2 \mathrm{mM} \mathrm{ATP \text {, }}$ 


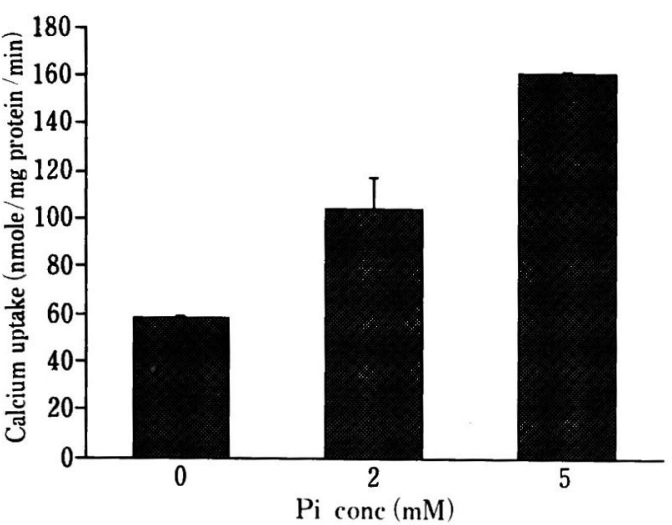

Fig. 6 Effect of $\mathrm{Pi}$ on $\mathrm{Ca}^{2+}$ uptake by chondrocytes. Permeabilized cells were treated with ruthenium red and $\mathrm{Ca}^{2+}$ accumulation in the presence of $\mathrm{Pi}(0-5 \mathrm{mM})$ was determined over a 15-minute time period.

there was a significant increase in $\mathrm{Ca}^{2+}$ accumulation and after 30 minutes, ATP increased the cell $\mathrm{Ca}^{2+}$ content two-fold. The rate of $\mathrm{Ca}^{2+}$ accumulation was $0.1 \mu \mathrm{mole} / \mathrm{mg}$ protein/ min. This value is comparable to rates for permeabilized liver cells $(0.3 \mu \mathrm{mol} / \mathrm{mg}$ protein/ min) under similar conditions.

Chondrocyte $\mathrm{Ca}^{2+}$ uptake was dependent on the ATP concentration. Figure 3 shows that maximum $\mathrm{Ca}^{2+}$ accumulation occurred when the ATP concentration was $5 \mathrm{mM}$. We also examined the ability of nucleotides other than ATP to support cell $\mathrm{Ca}^{2+}$ uptake. We found that UTP and to a lesser extent ADP promoted $\mathrm{Ca}^{2+}$ uptake by permeabilized chondrocytes (Fig. 4). GTP had no discernible effect on $\mathrm{Ca}^{2+}$ accumulation.

The aim of the second experiment series was to determine whether or not a $\mathrm{Ca}^{2+}$ pool, which was sensitive to metabolic signals, existed in the chondrocyte endoplasmic reticulum. Figure 5 indicated that $\mathrm{IP}_{3}$ caused a dramatic loss of $\mathrm{Ca}^{2+}$ from permeabilized cells that had been preloaded with $\mathrm{Ca}^{2+}$. The rate of release appeared to be very rapid in the first $10 \mathrm{~min}$ utes; exposure to the agent for an other 10 minutes resulted in a slower, although significant decrease in the cell $\mathrm{Ca}^{2+}$ concentration. A concentration of $2 \mu \mathrm{M} \mathrm{IP} \mathrm{IP}_{3}$ provided maximum $\mathrm{Ca}^{2+}$ release form permeabilized cells.

The effect of the metabolic intermediates

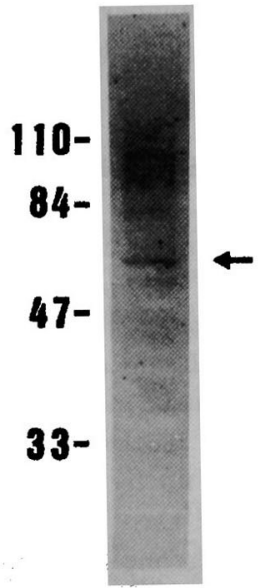

Fig. 7 Electrophoretic separation of $\mathrm{Ca}^{2+}$ binding proteins of chondrocyte endoplasmic reticulum obtained from chick embryos. Chondrocytes were homogenized and an endoplasmic reticulum fraction isolated by differential centrifugation. This protein fraction was subjected to SDS-PAGE in $10 \%$ acrylamide. The proteins were transferred to nitrocellulose and incubated with ${ }^{45} \mathrm{Ca}^{2+}$. The presence of $\mathrm{Ca}^{2+}$ binding proteins were visualized by autoradiography. An arrow indicates a major $\mathrm{Ca}^{2+}$ binding band.

glucose 6-phosphate and glucose as well as phosphate ions on $\mathrm{Ca}^{2+}$ uptake and release by the permeabilized chondrocytes was determined. Neither glucose nor glucose 6-phosphate influenced $\mathrm{Ca}^{2+}$ transport by chondrocytes (data not shown). In contrast, $\mathrm{Pi}$ modified $\mathrm{Ca}^{2+}$ uptake characteristics of the permeabilized cells in the presence of $2 \mathrm{mM}$ ATP. Figure 6 clearly shows that an increase in the medium $\mathrm{Pi}$ concentration from 0 to $5 \mathrm{mM}$ resulted in 3 fold increase in the rate of cell $\mathrm{Ca}^{2+}$ uptake. This result clearly indicated that any mechanism that could serve to elevate the Pi concentration would serve to maintain $\mathrm{Ca}^{2+}$ within the endoplasmic reticulum; alternatively, $\mathrm{Pi}$ depletion in the membrane would facilitate $\mathrm{Ca}^{2+}$ release.

Finally, proteins of the endoplasmic reticulum of chondrocytes were examined to ascertain whether they contained $\mathrm{Ca}^{2+}$ binding proteins (Fig. 7). Following electrophoresis and blotting onto nitrocellulose, a prominent $\mathrm{Ca}^{2+}$ binding band (molecular weight of 65,000 ) 
was observed. A number of minor bands with molecular weights of 80,000 and 100,000 daltons were also present.

\section{Discussion}

While it is recognized that the endoplasmic reticulum serves to control calcium flux, little was known of the characteristics of this system in chondrocytes. Using a permeabilized cell preparation in which mitochondrial calcium uptake had been blocked, we showed that calcium was taken up by a chondrocyte membrane system ; that $\mathrm{Ca}^{2+}$ binding proteins existed in the endoplasmic reticulum that were of the same size as reticuloplasmins ${ }^{8)}$; that ATP was required for cation accumulation ; that $\mathrm{Ca}^{2+}$ uptake was blocked when the cells were treated with an ATPase inhibitor; and that the $\mathrm{Ca}^{2+}$ pool was responsive to a known modulator of reticulum bound $\mathrm{Ca}^{2+}$. Together these findings indicate that there exists a $\mathrm{Ca}^{2+}$ binding system within the chondrocyte, probably associated with the endoplasmic reticulum, that serves to regulate ion transport. Considerable similarities in $\mathrm{Ca}^{2+}$ transport characteristics were seen between chondrocyte and other cell types ${ }^{6,7)}$. We showed, for the first time, that an $\mathrm{IP}_{3}$ sensitive $\mathrm{Ca}^{2+}$ pool was present in the endoplasmic reticulum. The rate and extent of $\mathrm{Ca}^{2+}$ release was similar in magnitude to that of other tissues ${ }^{6}$. Measurement of the time course of $\mathrm{Ca}^{2+}$ release showed that there was an initial rapid release followed by a slower phase-this was probably due to $\mathrm{Ca}^{2+}$ reuptake by the endoplasmic reticulum. A similar course is seen with pancreatic islet cells ${ }^{15)}$. The observation that $\mathrm{Ca}^{2+}$ uptake required ATP or other high energy donors and was blocked by vanadate suggested that nucleotide hydrolysis was a requirement for cation binding. That GTP had no measurable effect on $\mathrm{Ca}^{2+}$ accumulation was not surprising, as a recent study showed that this nucleotide might modulate $\mathrm{IP}_{3}$ dependent cation release ${ }^{19)}$.

Evaluation of the proteins in the endoplasmic reticulum indicated that there existed one major protein and up to 3 minor proteins which bound $\mathrm{Ca}^{2+}$. They had similar molecular weights as the reticuloplasmins, the luminal content of the endoplasmic reticulum ${ }^{8)}$. In terms of molecular weight, the chondrocyte protein is similar in weight to calsequestrin and calreticulin, 55 and $59 \mathrm{kd}$ proteins of plasmacytoma and liver cells respectively8,20).

We conducted experiments to ascertain whether glucose 6-phosphate could modulate $\mathrm{Ca}^{2+}$ uptake by the permeabilized chondrocytes. As cation transport has been linked with glucose 6-phosphatase activity in pancreatic islets $^{10,15)}$, we measured the activity of this enzyme in sections of the avian growth cartilage. In contrast to other cell types, glucose 6-phosphate has no significant effect on $\mathrm{Ca}^{2+}$ uptake (or release) by chondrocytes. The finding that the activity of this enzyme was very low suggested that a mechanism that linked phosphorylosis of glucose esters to calcium accumulation might not be functional in chondrocytes.

While there was minimal phosphatase activity and exogenous glucose 6-phosphate did not stimulate $\mathrm{Ca}^{2+}$ transport, the possibility existed that $\mathrm{Pi}$ alone might serve as a metabolic trap for the cation. To evaluate this possibility, cells were permeabilized and $\mathrm{Ca}^{2+}$ uptake determined in the presence of $\mathrm{Pi}$. $\mathrm{Re}$ sults of the experiment clearly showed that this anion markedly increased $\mathrm{Ca}^{2+}$ uptake. This finding suggests that any mechanism that could serve to elevate the intracellular $\mathrm{Pi}$ concentration, whether by hydrolysis of organic phosphate esters or by supplementing the cytosolic phosphate concentration, would serve to maintain $\mathrm{Ca}^{2+}$ within the endoplasmic reticulum. This dramatic effect of $\mathrm{Pi}$ on $\mathrm{Ca}^{2+}$ binding to the endoplasmic reticulum lends further importance to our earlier observation concerning $\mathrm{Pi}$ control of $\mathrm{Ca}^{2+}$ transport. Those studies showed that in model systems, the $\mathrm{Pi}$ concentration regulated $\mathrm{Ca}^{2+}$ transport across a lipid interphase ${ }^{1)}$; we also showed that at the cartilage calcification front, the appearance of $\mathrm{Pi}$ atoms in the matrix was coincident with mineral deposition 2,21). Results of all of these studies point to a more central role of intracellular $\mathrm{Pi}$ on chondrocyte $\mathrm{Ca}^{2+}$ transport and the mineralization process that has hitherto been reported. 
抄録：本研究では、ニワトリ軟骨細胞の小胞体(ER)の $\mathrm{Ca}^{2+}$ 結合の特徵を検索した。すなわち, digitonin で透過性を高めた細胞を用い, ミトコンドリヤの $\mathrm{Ca}^{2+}$ の取り込みを ruthenium red で阻害後, $\mathrm{Ca}^{2+}$ の取 り込みおよび放出に対する vanadate, ATP, 1, 4,5-inositol triphosphate $\left(\mathrm{IP}_{3}\right)$, glucose, glucose 6-phosphate および無機リン $(\mathrm{Pi})$ の影響を検討した。

その結果, $\mathrm{Ca}^{2+}$ の取り込みは, vanadate で阻害され ATP 添加で增加すること, Pi は ATP に依存し た $\mathrm{Ca}^{2+}$ の取り込みを著しく增加させること, IP ${ }_{3}$ は $\mathrm{ER}$ に蓄積された $\mathrm{Ca}^{2+}$ の放出を促すことが判明し た。しかし，glucose 6-phosphate はほとんど影響しなかった。また，ER に reticuloplasmin と同し分子 量の $\mathrm{Ca}^{2+}$ 結合蛋白が存在することが示された。以上の所見から，細胞内 $\mathrm{Pi}$ 上昇させるよらな機構が $\mathrm{ER}$ の $\mathrm{Ca}^{2+}$ 維持に働いており, 細胞内 $\mathrm{Pi}$ が軟骨の $\mathrm{Ca}$ の移動に中心的な役割を演じていることが示された。

\section{References}

1) Yaari, A.M., Shapiro, I.M. and Brown, C.E. : Evidence that phosphatidylserine and inorganic phosphate may mediate calcium transport during calcification. Biochem. Biophys. Res. Commun. $105:$ 778-784, 1982.

2) Kakuta, S., Golub, E.E. and Shapiro, I.M. : Morphochemical analysis of phosphorus pools in calcifying cartilage. Calcif. Tiss. Int. 37 : 293-299, 1985.

3) McCormack, J.G. and Denton, R.M. : Role of calcium ions in the regulation of intramitochondrial metabolism. Biochem. J. 190 : 95-105, 1980.

4) Lehninger, A.L. : Mitochondria and calcium ion transport. Biochem. J. $119: 129-138$, 1970.

5) Brighton, C.T. and Hunt, R. : Mitochondrial calcium and its role in calcification. Clin. Orthopaed. Rel. Res. 100 : 406-416, 1974.

6) Schulz, I., Thevenod, F. and DehlingerKremer, M. : Modulation of intracellular free $\mathrm{Ca}^{2+}$ concentration by $\mathrm{IP}_{3}$-sensitive and $\mathrm{IP}_{3}$-insensitive nonmitochondrial $\mathrm{Ca}^{2+}$ pools. Cell Calcium $10:$ 325-336, 1989.

7) Shoshan-Barmatz, V. : Stimulation of $\mathbf{C a}^{2+}$ efflux from sarcoplasmic reticulum by preincubation with ATP and inorganic phosphate. Biochem. J. 247 : 497-504, 1987.

8) Macer, D.R.J. and Koch, G.L.E. : Identification of a set of calcium-binding proteins in reticuloplasm, the luminal content of the endoplasmic reticulum. J. Cell Sci. 91 : 6170, 1988.

9) Volpe, P., Krause, K.-H., Hashimoto, S., Zorzato, F., Pozzan, T., Meldoles, J. and Lew, D.P. : "Calciosome" a cytoplasmic organelle: The inositol 1,4,5-triphosphatesensitive $\mathrm{Ca}^{2+}$ store of nonmuscle cells ? Proc. Natl. Acad. Sci. USA. 85 : 1091-1095, 1988.

10) Rana, R.S., Sekar, M.C., Hokins, L.E. and
MacDonald, M.J. : A possible role for glucose metabolites in the regulation of inositol1, 4,5-trisphosphate 5-phosphomonoesterase activity in pancreatic islets. J. Biol. Chem. 261 : 5237-5240, 1986.

11) Downes, P. and Michell, R.H. : Phosphatidylinositol 4-phosphate and phosphatidylinositol 4,5-bisphosphate : lipids in search of a function. Cell Calcium $3: 467-502,1982$.

12) Lynch, R.M. and Paul, R.J. : Compartmentation of carbohydrate metabolism in vascular smooth muscle: evidence for at least two functionally independent pools of glucose 6phosphate. Biochim. Biophys. Acta 887 : 315 $-318,1986$.

13) Berridge, M.J.: Calcium oscillations. J. Biol. Chem. 265 : 9583-9586, 1990.

14) Golub, E.E., Schattschneider, S.C., Berthold, P., Burke, A. and Shapiro, I.M. : Induction of chondrocyte vesiculation in vitro. J. Biol. Chem. $258: 616-621,1983$.

15) Wolf, B.A., Colca, J.R., Comens, P.G., Turk, J. and McDaniel, M.L. : Glucose 6-phosphate regulates $\mathrm{Ca}^{2+}$ steady state in endoplasmic reticulum of islets. J. Biol. Chem. 261 : 16284 -16287, 1986.

16) Maruyama, K., Mikawa, T. and Ebashi, S. : Detection of calcium binding proteins by ${ }^{45} \mathrm{Ca}$ autoradiography on nitrocellulose membrane after sodium dodecyl sulfate gel electrophoresis. J. Biochem. 95 : 515-519, 1984.

17) Lowry, O.H., Rosebrough, N.J., Farr, A.L. and Randall, R.J. . Protein measurement with the folin phenol reagent. J. Biol. Chem. 193 : 265-275, 1951.

18) Watts, D.C. and Faraj, I.J. . Glucose-6phosphatase in myotonic mice. Biochem. Soc. Trans. $18: 260-261,1990$.

19) Dawson, A.P. and Comerford, J.G. : Fffects of GTP on $\mathrm{Ca}^{2+}$ movements across endoplasmic reticulum membranes. Cell Calcium 10 : 343-350, 1989.

20) Treves, S., De Mattei, M., Lanfredi, M., 
Villa, A., Green, M., MacLennan, D.H., Meldolesi, J. and Pozzan, T. : Calreticulin is a candidate for calsequestrin-like function in $\mathrm{Ca}^{2+}$-storage compartments (calciosomes) of liver and brain. Biochem. J. 271 : 473$480,1990$.
21) Boyde, A. and Shapiro, I.M. : Morphological observations concerning the pattern of mineralization of the normal and the rachitic chick growth cartilage. Anat. Embryol. 175 : 457-466, 1987. 